Postgrad. MED. J. (1965), 41, 706.

Clinical Trial

\title{
TRIAL OF A TRIAMTERENE-BENZTHIAZIDE COMBINATION (DYTIDE)
}

\author{
R. A. Thompson, M.B., M.R.C.P. \\ University College Hospital, W.C.1.
}

\author{
M. F. CROWLEY, B.Sc. \\ Whittington Hospital, N.19.
}

THE USE of thiazide diuretics for the control of oedema in heart failure and other conditions is commonplace. In many instances these drugs are used over long periods, but unfortunately one of the drawbacks of their long-term use can be the development of electrolyte imbalance states, especially hypokalaemia. This is particularly dangerous when associated with digitalis therapy. Hypokalaemia can be prevented by potassium replacement therapy but this is often unpleasant because of the size and number of tablets required, and of their taste. When a patient is having a variety of tablets, the potassium tablets are often the first to be omitted or reduced should he feel out of sorts for any reason.

'Dytide', a preparation of triamterene combined with benzthiazide, has recently been introduced for clinical use. Benzthiazide is a thiazide derivative with an action comparable to hydrochlorothiazide (Ford, 1960). Triamterene, a pteridine derivative, has an effective diuretic and natriuretic action and does not cause a loss of potassium (Wiebelhaus, Weinstock, Brennan, Sosnowski and Larsen, 1961; Crosley, Ronquillo, Strickland and Alexander, 1962; Baba, Tudhope and Wilson, 1962); it has been shown to act on the distal renal tubules (Baba and others, 1964) and a number of investigators have suggested that it therefore augments the action of thiazide derivatives which act on the proximal tubules, while at the same time inhibiting the associated potassium loss (Donnelly, Turner and Sowry, 1962; Cattell and Havard, 1962; Baba; Tudhope and Wilson, 1962; Nielson, 1964). Thus, a combination of triamterene with a thiazide diuretic could be considered to be suitable for treating oedematous patients, especially over a prolonged period, without the need for supplementary potassium therapy. This combination has been used successfully by Golaszewski and Healy (1963) and by Golaszewski, Lazarus and Healy (1964), who found it more effective than triamterene alone.

It was decided to evaluate 'Dytide' in oedematous patients in whom diuretics would normally be used, and to assess its ability to maintain the serum potassium level within normal limits when given over prolonged periods.

\section{Methods and Material}

Investigations: Patients were weighed before treat- ment and twice weekly thereafter while in hospital $\vec{\overrightarrow{ }}$ (with the exception of Case 11). Before diuretic $\omega$ therapy was commenced, and weekly thereafter blood $\frac{}{8}$ was taken for the investigation of serum electrolytes; 0 the estimation of the serum potassium and urea being 3 . undertaken on all occasions and other electrolyte $A$ estimations when considered necessary. Before treat- $\overrightarrow{.}$ ment a 24-hour urine specimen was sent for sodium $\infty$ and potassium estimations, which were repeated on $\rightarrow$ the 7th day after starting 'Dytide'. (In three patients, $ح$ on admission, diuretic therapy could not be withheld o for 24 hours, therefore mersalyl was immediately 은 given; in two of these patients it was then possible to withhold other diuretics for a further 24 hours $Z$ and allow for the appropriate blood and urine 0 collections to be taken.)

Dosage: Each capsule of 'Dytide' contains $50 \mathrm{mg}$ of triamterene and $25 \mathrm{mg}$. of benzthiazide. Two capsules were given in the morning and the third capsule in the early afternoon in order to obtain the main diuretic effect during waking hours. The o dosage was continued for a week and if the diuret. response proved to be satisfactory the dose was thent reduced to two capsules daily, and subsequently, in Out-patients, to two capsules a day on alternate days.

Evaluation of Treatment: The response to therapy was assessed by the improvement in the clinical $\mathbb{D}$ state, by the diminution of oedema and by the loss of weight.

Associated therapy (digitalis, antibiotics, oxygen, etc.) was prescribed when considered desirable, no potassium supplements were given. The patients were given the standand wand diet without added salt. After discharge the patients were examined in the Out-Patients' Department at fortnightly and monthly intervals as required by their clinical state. They were then weighed and blood was taken on every occasion for serum urea and serum potassium, and for any other investigations considered necessary.

Urea was estimated by the method described by Skeggs (1957), and Marsh, Fingerhut and Kirsch 을 (1957), using the Technicon "Autoanalyser". Sodium $>$ and potassium were estimated by flame photometry, and uric acid by the method of Feichtmeir and Wrenn (1955).

\section{Results}

Twenty-two patients were investigated, of whom eleven were males and eleven females. The average age of the males was 65 and that of the 0

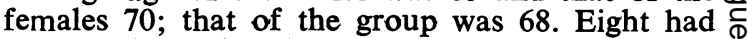
had previous diuretic and other therapy at home ? and were admitted because of a deterioration in 7 their condition. 
TABLE 1

\begin{tabular}{|c|c|c|c|c|c|c|c|}
\hline $\begin{array}{l}\text { Case } \\
\text { No. }\end{array}$ & Diagnosis & Age & Sex & $\begin{array}{l}\text { Clinical } \\
\text { Response }\end{array}$ & $\begin{array}{l}\text { Loss } \\
\text { of Wt. } \\
\text { on } \\
7 \text { th day } \\
\text { in lbs. }\end{array}$ & $\begin{array}{l}\text { Total } \\
\text { stay } \\
\text { in } \\
\text { hospital } \\
\text { in days }\end{array}$ & $\begin{array}{l}\text { Wt. loss } \\
\text { at end } \\
\text { of } \\
\text { hospital } \\
\text { stay }\end{array}$ \\
\hline 1 & Hypertension & 68 & $\mathbf{F}$ & satisfactory & 5 & 14 & 7 \\
\hline 2 & $\begin{array}{l}\text { Cor pulmonale } \\
\text { Chronic bronchitis }\end{array}$ & 63 & $\mathbf{M}$ & satisfactory & 8 & 15 & 8 \\
\hline 3 & $\begin{array}{l}\text { Mitral incompetence } \\
\text { Auricular fibrillation }\end{array}$ & 71 & F & satisfactory & 9 & 28 & 10 \\
\hline 4 & Kyphoscoliosis & & & salistactory & & & 10 \\
\hline 5 & $\begin{array}{l}\text { Pneumonia-cor pul. } \\
\text { Rheumatic ht. disease }\end{array}$ & 63 & $\mathbf{M}$ & satisfactory & 12 & 35 & 15 \\
\hline 6 & Auricular fibrillation & 63 & F & satisfactory & 4 & 30 & 36 \\
\hline & Auricular fibrillation & 66 & $\mathbf{M}$ & satisfactory & 10 & 14 & 17 \\
\hline 7 & $\begin{array}{l}\text { Cardiomyopathy ? Myeloma } \\
\text { Auricular fibrillation }\end{array}$ & 76 & $\mathbf{M}$ & satisfactory & 25 & 17 & 36 \\
\hline 8 & $\begin{array}{l}\text { Cor pulmonale } \\
\text { Chronic bronchitis }\end{array}$ & 73 & $\mathbf{M}$ & satisfactory & 8 & 28 & 39 \\
\hline 9 & Rheumatic ht. disease & 51 & $\underset{\mathbf{M}}{\mathbf{M}}$ & satisfactory & 8 & 10 & $\begin{array}{l}8 \\
9\end{array}$ \\
\hline 11 & $\begin{array}{l}\text { Rheumatic ht. disease } \\
\text { Acute myocardial infarct. } \\
\text { Left ventricular failure. }\end{array}$ & $\begin{array}{l}6 / \\
66\end{array}$ & $\mathbf{F}$ & $\begin{array}{l}\text { satistactory } \\
\text { satisfactory }\end{array}$ & N.K. & $\begin{array}{l}14 \\
35\end{array}$ & N.K. \\
\hline $\begin{array}{l}12 \\
13\end{array}$ & $\begin{array}{l}\text { Ischaemic ht. disease } \\
\text { Cor pulmonale } \\
\text { Chronic bronchitis }\end{array}$ & $\begin{array}{l}74 \\
70\end{array}$ & $\begin{array}{l}\mathbf{F} \\
\mathbf{M}\end{array}$ & $\begin{array}{l}\text { partial response } \\
\text { partial response }\end{array}$ & $\begin{array}{l}5 \\
7\end{array}$ & $\begin{array}{l}21 \\
14\end{array}$ & $\begin{array}{r}4 \\
10\end{array}$ \\
\hline $\begin{array}{l}14 \\
15 \\
16\end{array}$ & $\begin{array}{l}\text { Cardiomyopathy } \\
\text { Coarctation of aorta } \\
\text { Hypertension } \\
\text { Digitalis intoxication }\end{array}$ & $\begin{array}{l}63 \\
59 \\
78\end{array}$ & $\begin{array}{l}\mathbf{M} \\
\mathbf{M} \\
\mathbf{F}\end{array}$ & $\begin{array}{l}\text { partial response } \\
\text { partial response } \\
\text { partial response }\end{array}$ & $\begin{array}{r}10 \\
+3 \\
8\end{array}$ & $\begin{array}{l}17 \\
10 \\
24\end{array}$ & $\begin{array}{l}16 \\
+3^{*} \\
23\end{array}$ \\
\hline $\begin{array}{l}17 \\
18\end{array}$ & $\begin{array}{l}\text { Rheumatic ht. disease } \\
\text { Cor pulmonale } \\
\text { Chronic bronchitis }\end{array}$ & $\begin{array}{l}76 \\
67\end{array}$ & $\begin{array}{l}\mathbf{F} \\
\mathbf{M}\end{array}$ & $\begin{array}{l}\text { partial response } \\
\text { no response }\end{array}$ & $\begin{array}{l}6 \\
1\end{array}$ & $\begin{array}{l}24 \\
13\end{array}$ & 12 \\
\hline $\begin{array}{l}19 \\
20 \\
21\end{array}$ & $\begin{array}{l}\text { Nephrotic syndrome } \\
\text { Hypertension } \\
\text { Ischaemic ht. disease } \\
\text { Left ventricular failure }\end{array}$ & $\begin{array}{l}70 \\
72 \\
66\end{array}$ & $\begin{array}{l}\mathbf{F} \\
\mathbf{F} \\
\mathbf{M}\end{array}$ & $\begin{array}{l}\text { no response } \\
\text { no response } \\
\text { no response }\end{array}$ & $\begin{array}{r}5 \\
2 \\
\text { nil }\end{array}$ & $\begin{array}{l}58 \\
14 \\
17\end{array}$ & $\underset{\text { nil }}{3 \dagger}$ \\
\hline 22 & $\begin{array}{l}\text { Cor pulmonale } \\
\text { Chronic bronchitis }\end{array}$ & 65 & $\mathbf{F}$ & $\begin{array}{l}\text { drug stopped } \\
\text { side effects }\end{array}$ & 8 & 17 & - \\
\hline
\end{tabular}

* See text for explanation

$\dagger$ Defaulted after 1st. O-P appt.

In one patient the fluid retention was caused by the nephrotic syndrome secondary to renal amyloidosis and in the remaining 21 patients it was caused by cardiac failure. Heart failure was attributed to cor pulmonale in six patients, valvular heart disease (5), ischaemic heart disease (3), hypertension (3), and coarctation of the aorta in one. In the remaining three cases the cause of the heart failure was obscure but in two of these three patients it was probably due to alcoholic cardiomyopathy.

Of the 21 patients treated, 11 showed a successful clinical response, six a partially successful clinical response and five were considered failures.

\section{Successful Response}

Eleven patients were maintained reasonably symptom-free, without side effects, with 'Dytide' as the only diuretic. Four had clinically detectable ankle oedema but this was their usual "normal" state and was not considered significant.

\section{Partially Successful Response}

Six patients were considered only partially

successful. Four of these (Cases 12, 13, 14 and 16, in Table 1) showed an initial favourable response to 'Dytide' alone but either deteriorated or failed to maintain this response and required the addition of twice-weekly mersalyl injections. The mersalyl injections were not required until after $10,11,16$ and 2 weeks respectively. Three of these four patients $(12,13$, and 16) had had several previous admissions for exacerbations of chronic heart failure and had been previously receiving daily diuretics. Patient No. 16, with hypertensive and ischaemic heart disease, had been admitted with digitalis toxicity. She improved with treatment and was discharged from hospital without ECG evidence of digitalis toxicity but unfortun- o ately died two weeks later at home in severe left $\mathrm{N}$ ventricular failure. A fifth patient (15) with severe $\mathcal{N}$ coarctation of the aorta and congestive failure $\omega$ had previously responded to vigorous hospital treatment with digoxin, thiazides, mersalyl and o paracentesis abdominis. His oral diuretic was $\mathbb{\varnothing}$ changed to 'Dytide' and the mersalyl ( 2 cc. once ? weekly) was continued; he was maintained well 0 and oedema-free for six months. The sixth patient 
TABLE 2

Variation in Serum Potassium Levels

\begin{tabular}{|c|c|c|c|c|c|}
\hline Case no. & $\begin{array}{l}\text { No. of times } \\
\text { serum } K<3.5^{*}\end{array}$ & $\begin{array}{l}\text { No. of times } \\
\mathrm{K}=3.5-4.0^{*}\end{array}$ & $\begin{array}{l}\text { No. of times } \\
K=4.0^{-}-5.0^{*}\end{array}$ & $\begin{array}{l}\text { No. of times } \\
\mathbf{K}=5.0-5.5^{*}\end{array}$ & $\begin{array}{l}\text { No. of times } \\
\mathbf{K}<5.5^{*}\end{array}$ \\
\hline $\begin{array}{l}1 \\
2 \\
3 \\
4 \\
5 \\
6 \\
7 \\
8 \\
9\end{array}$ & $\begin{array}{c}\text { Nil } \\
1 \\
\text { Nil } \\
1 \\
1 \\
\text { Nil } \\
\text { Nil } \\
\text { Nil } \\
\text { Nil }\end{array}$ & $\begin{array}{c}2 \\
1 \\
1 \\
2 \\
4 \\
\text { Nil } \\
2 \\
1 \\
\text { Nil }\end{array}$ & $\begin{array}{l}5 \\
2 \\
5 \\
5 \\
2 \\
5 \\
3 \\
8 \\
4\end{array}$ & $\begin{array}{c}\text { Nil } \\
\text { Nil } \\
1 \\
\text { Nil } \\
\text { Nil } \\
1 \\
\text { Nil } \\
\text { Nil } \\
\text { Nil }\end{array}$ & $\begin{array}{l}\text { Nil } \\
\text { Nil } \\
\text { Nil } \\
\text { Nil } \\
\text { Nil } \\
\text { Nil } \\
\text { Nil } \\
\text { Nil } \\
\text { Nil }\end{array}$ \\
\hline $\begin{array}{l}10 \\
11 \\
12 \\
13 \\
14 \\
15 \\
16 \\
17\end{array}$ & $\begin{array}{l}\text { Nil } \\
\text { Nil } \\
\text { Nil } \\
1 \\
\text { Nil } \\
\text { Nil } \\
\text { Nil } \\
\text { Nil }\end{array}$ & $\begin{array}{c}\text { Nil } \\
\text { Nil } \\
1 \\
1 \\
3 \\
3 \\
\text { Nil } \\
\text { Nil }\end{array}$ & $\begin{array}{l}1 \\
4 \\
4 \\
4 \\
6 \\
2 \\
3 \\
2\end{array}$ & $\begin{array}{l}2 \\
\text { Nil } \\
\text { Nil } \\
\text { Nil } \\
\text { Nil } \\
\text { Nil } \\
\text { Nil } \\
\text { Nil }\end{array}$ & $\begin{array}{l}\text { Nil } \\
\text { Nil } \\
\text { Nil } \\
\text { Nil } \\
\text { Nil } \\
\text { Nil } \\
\text { Nil } \\
\text { i }\end{array}$ \\
\hline
\end{tabular}

* Figures given in mEq./litre.

(17) had responded well as an in-patient but when seen at Out-patients two weeks after discharge she was rather more breathless, with increase in weight and a slight ankle swelling. Her 'Dytide' was increased from two to three capsules daily but unfortunately she died in her sleep ten days later.

\section{Poor Response}

In four patients a satisfactory diuresis was not obtained using 'Dytide'. One patient aged 67 with severe cor pulmonale, with a long history of previous admissions, failed to improve after a week on digoxin, anti-biotics and 'Dytide'; he died after a further week on other intensive diuretic therapy. Another patient, aged 70 with a nephrotic syndrome due to amyloidosis secondary to chronic rheumatoid arthritis, gave an initial favourable response to 'Dytide' with a $5 \mathrm{lb}$. loss of weight in the first week; however, this improvement was not maintained and she made a weight gain of $8 \mathrm{lb}$. in the second week. 'Dytide' wàs dis-continued and diuresis was eventually effected by a combination of mersalyl, chlorothiazide and spironolactone. A patient with mild left ventricular failure (No. 21) failed to respond and 'Dytide' was withdrawn because there was a considerable rise in the blood urea (from 39 to $72 \mathrm{mg}$. $/ 100 \mathrm{ml}$.) which settled on withdrawal of the drug. A fifth patient (22) with chronic bronchitis and cor pulmonale who was being treated with digoxin, antibiotics and three capsules of 'Dytide' daily developed anorexia and weakness. Although there was a loss of $8 \mathrm{lbs}$. in weight her blood urea rose from 42 to $103 \mathrm{mg}$. / $100 \mathrm{ml}$. On withdrawal of 'Dytide' she felt better and her blood urea returned to pre-treatment levels.

\section{Results of Biochemical Investigations}

Serum Potassium Levels

Potassium levels were maintained for the mos part within the normal range (Table 2). Patients 2,4 and 5 showed, on one occasion each, $\vec{\oplus}$ serum potassium of just below $3.5 \mathrm{mEq}$./1. durin the course of treatment; these low figures wefe seen in the early stages during the maximum diuresis and they reverted to normal values without a further change in treatment. In the five patients who were given mersalyl as additional therapy there was also a transitory fall in the serum potassium, and a rise in the blood urea after starting the injections but in the next two or three weeks they returned to their previous levels. In one patient (17) the serum potassium rose to $5.85 \mathrm{mEq} . / 1$. on one occasion. No instance of hyperkalaemia occurred.

\section{Urinary Electrolytes}

The urinary electrolyte excretion on the 7 th day of treatment with 'Dytide' was compared with the pattern of electrolyte excretion in the first 24 hours of hospital admission, before 'Dytide' was exhibited. At the end of the 1st. week of treatment, such changes towards improvement as are brought about by general therapy (e.g. bed rest, control of infection, reduction in pulse rate, o etc.), might reasonably be supposed to have ex- $N$ erted their maximum effect, and the urinary electrolyte pattern on the 7th day can be assumed to be influenced mainly by the diuretic agent.

The mean changes in the 24-hour urinary sodium and potassium levels and the mean weight $\mathbb{D}$ changes, after one week's treatment, are shown $\stackrel{0}{?}$ in Table 3. Patients who responded to 'Dytide' clinically had higher values for 24 -hour sodium 
TABLE 3

\begin{tabular}{|c|c|c|c|}
\hline & $\begin{array}{l}\text { Mean wt. loss (lbs) } \\
\text { after } 7 \text { days } \\
\text { on 'Dytide' }\end{array}$ & $\begin{array}{l}\text { Mean change in } \\
24 \text { hour Na output } \\
\text { (mEq.)* }\end{array}$ & $\begin{array}{l}\text { Mean change in } \\
24 \text { hour } \mathrm{K} \text { output } \\
(\mathrm{mEq})^{*}\end{array}$ \\
\hline $\begin{array}{c}\text { Satisfactory } \\
\text { Response } \\
\text { Group } \\
\text { (Cases } 1-11 \text { ) }\end{array}$ & -10 & +74.1 & +2.7 \\
\hline $\begin{array}{l}\text { Partial } \\
\text { Success Group } \\
\text { (Cases 12-17) }\end{array}$ & -5.5 & +55.0 & +9.2 \\
\hline $\begin{array}{l}\text { Poor Response } \\
\text { Group } \\
\text { (Cases 18-22) }\end{array}$ & -3.5 & -13.3 & +2.2 \\
\hline
\end{tabular}

* These figures express the mean difference between the 24 hour urine collection before treatment, and on the 7th day of 'Dytide'.

excretion on the 7th day of treatment as compared with pre-treatment. Patients who failed to respond had, with the exception of Case 19, lower values for 24-hour sodium excretion on the 7th day of treatment as compared with pre-treatment values. The mean potassium excretion, on the other hand, was increased to a much less extent in all groups. The potassium excretion was unchanged in one patient, decreased by amounts from 3 to $43 \mathrm{mEq}$. in eight patients and increased by amounts from 6 to $26 \mathrm{mEq}$. in 12 patients. The remaining patient (Case 2) appeared fairly insensitive, at the start of treatment, to the potassium retaining properties of triamterene. His 24-hour urinary potassium after seven days on 'Dytide' rose from 13 to $74 \mathrm{mEq}$. with a serum potassium of $3.3 \mathrm{mEq}$. $/ 1$. However without change of therapy, his serum potassium returned to normal levels and has remained so after 10 weeks of two capsules of 'Dytide' daily.

\section{Blood Urea}

Table 4 shows the blood urea levels for the 17 patients who showed a satisfactory or fairly satisfactory response to 'Dytide' therapy. Those patients in whom blood urea was elevated on admission usually showed a reduction in the subsequent weeks of treatment, which was associated with an improvement in the clinical state. In some patients who were kept on 'Dytide' daily for several weeks there was an increase in the blood urea level from the lowest value obtained. This elevation was unaccompanied by symptoms except in Case 10, where the patient was discharged in error on three capsules of 'Dytide' daily. She had been on three capsules daily for a fortnight with a satisfactory response but after being discharged, she failed to appear for her first follow-up appointment and was re-admitted three-and-a-half weeks later with a minor cerebrovascular accident, from which she completely recovered. The blood urea after six weeks on three capsules of 'Dytide' daily was $84 \mathrm{mg}$./100 $\mathrm{ml}$. but on stopping the drug rapidly fell to $31 \mathrm{mg}$. $/ 100 \mathrm{ml}$.
In four patients of the partial success group, there was a rise of blood urea after starting mersalyl therapy. In one (14) who was receiving two capsules 'Dytide' daily and once weekly injection of mersalyl, which was continued for 28 weeks, the blood urea rose to $80 \mathrm{mg}$. $/ 100 \mathrm{ml}$.

In Case 21 of the poor response group, the drug was withdrawn, as although there was a loss of weight of $8 \mathrm{lb}$. in the first week, the blood urea rose from 42 to $103 \mathrm{mg} . / 100 \mathrm{ml}$.

\section{Serum Uric Acid Levels}

Serum uric acid was estimated in 14 patients who had been treated with 'Dytide' for 10 weeks or more. In only two was the level above the normal of 3 to $6 \mathrm{mg}$. $/ 100 \mathrm{ml}$. In one patient (7) belived to be suffering from myelomatosis, the value, after ten weeks on 'Dytide', was 8.4 mg. $/ 100 \mathrm{ml}$. After a further four weeks treatment it was $7.9 \mathrm{mg} . / 100 \mathrm{ml}$. In another patient (13) the serum uric acid rose from $4.9 \mathrm{mg}$. $/ 100 \mathrm{ml}$. in the twelfth week of treatment to $8.4 \mathrm{mg}$. $/ 100 \mathrm{ml}$. in the sixteenth week. This was coincident with a rise in the blood urea after adding mersalyl and both the serum uric acid and blood urea returned to near previous levels without changing treatment.

\section{Side Effects}

Side effects, other than those associated with a rise in the blood urea, were a mild gastric intolerance in one patient and a transitory erythema in the legs in a second. Another patient, after five months on the drug, complained of falling hair but this improved although treatment was continued. No changes in blood pressure were recorded in patients not on hypotensive drugs.

\section{Discussion}

This triamterene-benzthiazide combination (triamterene $50 \mathrm{mg}$.; benzthiazide $25 \mathrm{mg}$.) is an effective diuretic. Some practitioners object to the use of fixed dose combinations of drug. Although no evidence was obtained of its superiority over 
TABLE 4

Blood Urea Responses at Various Treatment Levels

\begin{tabular}{|c|c|c|c|c|c|c|c|c|c|c|c|}
\hline 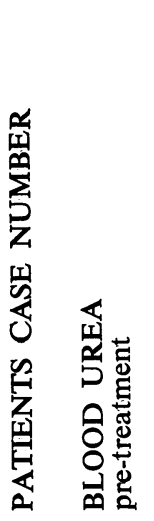 & 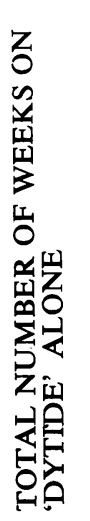 & 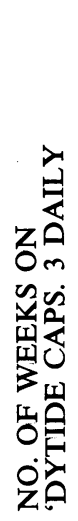 & 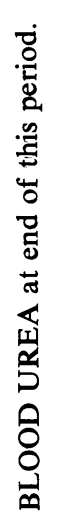 & 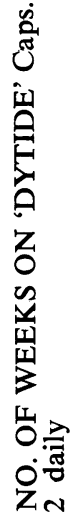 & 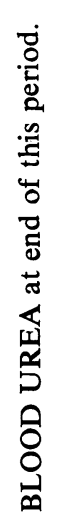 & 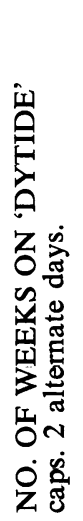 & 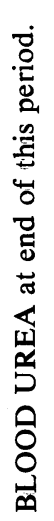 & 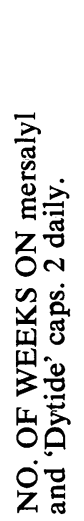 & 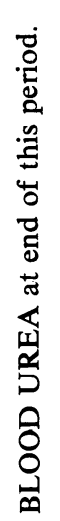 & 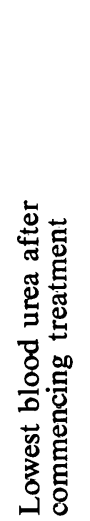 & 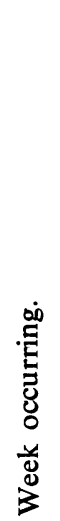 \\
\hline $\begin{array}{l}58 \\
30 \\
64 \\
58 \\
94 \\
90 \\
39 \\
51 \\
50 \\
34 \\
70 \\
46 \\
33 \\
48 \\
48 \\
46 \\
52\end{array}$ & $\begin{array}{r}25 \\
10 \\
14 \\
14 \\
27 \\
23 \\
16 \\
24 \\
16 \\
6 \\
5 \\
10 \\
10 \\
16 \\
0 \\
2 \\
6\end{array}$ & $\begin{array}{r}2 \\
1 \\
1 \\
2 \\
4 \\
1 \\
2 \\
1 \\
3 \\
6 \\
1 \\
10 \\
2 \\
2 \\
1\end{array}$ & $\begin{array}{l}54 \\
34 \\
51 \\
46 \\
60 \\
40 \\
36 \\
55 \\
52 \\
82 \\
72 \\
52 \\
54 \\
41 \\
50\end{array}$ & $\begin{array}{r}11 \\
9 \\
7 \\
12 \\
19 \\
4 \\
14 \\
5 \\
-5 \\
5 \\
9 \\
14 \\
5\end{array}$ & $\begin{array}{l}40 \\
46 \\
59 \\
27 \\
60 \\
65 \\
40 \\
56 \\
\overline{4} \\
44 \\
49 \\
\overline{-1} \\
59\end{array}$ & $\begin{array}{l}\frac{12}{6} \\
\frac{4}{4} \\
\frac{18}{18} \\
= \\
= \\
= \\
= \\
=\end{array}$ & $\begin{array}{l}\frac{44}{56} \\
\frac{54}{48} \\
\frac{48}{51} \\
- \\
- \\
- \\
- \\
- \\
-\end{array}$ & $\begin{array}{r}- \\
- \\
- \\
\overline{-} \\
\overline{-} \\
\overline{-} \\
\overline{-} \\
-- \\
\overline{-} \\
4 \\
7 \\
2 \\
28 \\
2 \\
-\end{array}$ & $\begin{array}{l}= \\
= \\
= \\
= \\
= \\
= \\
=- \\
-- \\
64 \\
63 \\
80 \\
49 \\
=-\end{array}$ & $\begin{array}{l}40 \\
34 \\
40 \\
26 \\
20 \\
40 \\
28 \\
42 \\
38 \\
44 \\
32 \\
47 \\
40 \\
38 \\
50 \\
41 \\
42\end{array}$ & $\begin{array}{r}25 \\
1 \\
2 \\
4 \\
2 \\
1 \\
1 \\
3 \\
1 \\
1 \\
1 \\
6 \\
8 \\
8 \\
1 \\
2 \\
2\end{array}$ \\
\hline
\end{tabular}

"No response" patients not included. Blood ureas expressed as $\mathrm{mg} . / 100 \mathrm{ml}$.

other diuretic agents this series of cases shows that it is possible for patients on 'Dytide' to maintain normal serum potassium levels without the requirement for potassium supplements. This permits electrolyte investigations in out-patients to be kept to a minimum in long term patients which might not be the case when the proportions of triamterene and thiazides were being varied. As an example one patient (5) had a tendency to a low normal serum potassium levels (3.5 to $4.0 \mathrm{mEq} . / 1$.) and it is reasonable to suppose that increasing the daily dose of benzthiazide would further depress her potassium levels.

The patients studied in this trial were, for the most part, well over middle age when the glomerular filtration rate is lower than in the young and blood urea levels of $50-60 \mathrm{mg}$. $/ 100 \mathrm{ml}$. may be considered normal. The continued use of 'Dytide' is, however, sometimes associated with a rise in the level of the blood urea, especially when given daily. This had been noted during the original trials with triamterene (Crosley and others, 1962; Donnelly and others, 1962; Shaldon and Ryder, 3 1962), and can usually be avoided if for routine use a daily dose of 3 or 4 capsules is not exceeded. This dosage should not be continued for longer than a week and if no response is being $\frac{}{\partial}$ obtained, an alternative diuretic should be tried. I If a diuresis has commenced and the patient is well, then the dose should be reduced to 2 capsules daily for another week or two, by which times the maximum diuresis will have been effected. $N$ If further maintenance therapy is required, it can $\mathbb{C}_{\mathrm{W}}$ usually be achieved by giving 'Dytide' on alternate ${ }_{\sigma}$ days. Should the drug be used daily for more than a few weeks, then periodic estimations of the blood urea and serum potassium should be under- $\mathbb{D}$ taken. In patients with evidence of renal im-? pairment, 'Dytide' like other diuretics, should be $\frac{0}{T}$ used with caution, if at all. 


\section{Summary}

A clinical trial has been carried out to evaluate the effect of a triamterene-benzthiazide combination ('Dytide') on the serum potassium levels of oedematous patients when used over prolonged periods without potassium supplement.

Twenty-two cases were treated of whom 17 had a satisfactory clinical response over periods from 5-28 weeks with maintenance of the serum potassium levels within normal limits. Four patients failed to achieve a satisfactory diuresis and one patient had to stop therapy because of an excessive rise in the blood urea.

An increase in the blood urea in patients taking 'Dytide' daily was not uncommon, especially if mersalyl was also given. It was usually not of clinical significance, and was always reversible on withdrawing the drug. It is recommended that patients on long term treatment with 'Dytide' should receive the drug on alternate days. If daily dosage is necessary, then periodic estimations of the blood urea and serum potassium should be made.

The authors are grateful to Drs. H. E. S. Pearson and E. Montuschi for allowing them to study the use of 'Dytide' in their patients, and for encouragement and advice. They would also like to thank Smith Kline and French Laboratories for the supply of 'Dytide' capsules.

\section{REFERENCES}

Baba, W. I., Tudhope, G. R., and Wilson, G. M. (1962): Triamterene, a New Diuretic Drug. Brit. med. J., ii, 756.

Baba, W. I., Tudhope, G. R., and Wilson, G. M. (1964): Site and Mechanism of Action of the Diuretic Triamterene. J. clin. Sci., 27, 181.

Cattell, W. R., and Havard, C. W. H. (1962): Diuretic Action of Triamterene in Man. Brit. med. J., ii, 1362.

Crosley, A. P., Ronquillo, L. M., Strickland, W. H., and Alexander, F. (1962): Triamterene, a new Natruretic Agent. Preliminary Observation in Man. Ann. intern. Med., 56, 241.

Donnelly, R. J., Turner, P., and Sowry, G. S. C. (1962): Clinical Trial of New Oral Diuretic-SKF 8542. Lancet, i, 245.

Feichmeir, T. V., and WrenN, H. T. (1955): Direct Determination of Uric Acid using Uricase. Amer. J. clin. Path., 25, 833.

Ford, R. V. (1960): Human Pharmacology of a New Non-mercurial Diuretic: Benzthiazide (Urese). Curr. ther. Res. $2,51$.

Golaszewski, J., and Healy, J. M. (1963): A Clinical Evaluation of a Combination of Two Oral Diuretics-Tritmterene and Benzthiazide. Brit. J. Dis. Chest. 57, 53.

Hauman, R. L., and Weller, J. M. (1960): Evaluation of 3-Benzylthiomethyl Chlorothiazide. A New Oral Diuretic, Clin. Pharmacol. Ther., 1, 175.

HAVARD, C. W. H., and WOOD, P. H. N. (1960): Clinical Evaluation of Benzthiazide, an Oral Diuretic, Brit. med. J., i, 1773.

Marsh, W. H., Fingerhut, B., and KIrSch, E. (1957): Determination of Urea Nitrogen with the Diacetyl Method and an Automatic Dialyzing Apparatus, Amer. J. clin. Path., 28, 681.

NiELSEN, O. E. (1964): Kliniske undersogelser over Diuretisk og Kaliumretinerende med et Klortiazidderwat (Triklormetiazid) samt over Stoffets Pavirkning af den renale Filtration, Ugeskr. Laeg., 126, 290.

Shaldon, S., and RYDER, J. A. (1962): Use of a Pteridine Diuretic (Triamterene) in Treatment of Hepatic Ascites, Brit. med. J., ii, 764.

SkegGS, L. T. (1957): An Automatic Method for Colorimetric Analysis, Amer. J. clin. Path., 28, 311

Swartz, C. Seller, R., Fuchs, M., Brest, A. N. and Moyer, J. H. (1963): Five Years' Experience with the Evaluation of Diuretic Agents, Circulation 28, 1042 .

Wiebelhaus, V. D., Weinstock, J., Brennan, F. T., SOSNOWSKI, G., and LARSEN, T. J. (1961): A Potent, Non-Steroidal Orally Active Antagonist of Aldosterone, Fed. Proc., 20, 409.

Golaszewski. J., Healy, J. M., and Lazarus, S. (1964): Treatment of Cardiac Oedema, by a Combination of Triamterene and Benzthiazide (Dytide), Med. Proc., 10, 377. 